\title{
УДК 656.078
}

UDC 656.078

\author{
Маяк М.М., Прогній П.Б. ${ }^{2}$, Матвіїшин А.Й. ${ }^{3}$, Попович П.В. ${ }^{2}$, Шевчук О.С. ${ }^{2}$, Островерхов В.М. ${ }^{2}$, \\ Коцур А.С. ${ }^{2}$, Романишин O.B. ${ }^{2}$ \\ ${ }^{1}$ Луцький національний технічний університет, Луцьк, Украӥна; ${ }^{2}$ Західноукрайнський \\ начіональний університет, Тернопіль, Украйна; ${ }^{3}$ Тернопільський національний технічний університет \\ імені Івана Пулюя, Тернопіль, Україна
}

\section{ОСОБЛИВОСТІ РОЗВИТКУ РИНКУ ВАНТАЖНИХ І ПАСАЖИРСЬКИХ ПЕРЕВЕЗЕНЬ}

\begin{abstract}
Проведено аналіз основних тенденцій розвитку ринку вантажних і пасажирських перевезень, досліджено базові фактори, що впливають на розвиток транспортних підприємств. Виконано огляд економічної активності у транспортній галузі країни. Досліджено основні залежності, динаміку та структурні особливості ринку пасажирських і вантажних перевезень, а також тенденції розвитку ринку транспортної логістики включаючи пасажирські і вантажні потоки за видами транспорту. Встановлено, що основними замовниками транспортних послуг є підприємства дорожньої та будівельної галузей, а також аграрні холдинги, в основному, виробники продукції рослинництва в сільськогосподарському секторі, що у комплексі забезпечило збільшення обсягів перевезення вантажів автомобільним і залізничним транспортом. Протягом п’яти крайніх років частка автомобільного транспорту в транспортній системі країни прогнозовано продовжує зростати на основі позитивного тренду збільшення попиту на перевезення вантажів для вказаних галузей, отже матиме місце тривалий динамічний розвиток транспортної галузі України в цілому. Ринок логістичних послуг та споживчий ринок мають пов'язані напрями розвитку, встановлено, що вони є збалансованими, в цілому ринок автомобільних та залізничних перевезень має стабільну тенденцію до зростання при можливому зниженні темпів. Результати дослідження можуть бути застосовані при виконанні моделювання матеріальних потоків на ринку перевезень вантажів, а також пасажирів, на основі результатів дослідження факторів, які впливають на розвиток транспортних підприємств країни, що якісно впливатиме на вдосконалення чи актуалізацію інструментарію планування діяльності транспортно - експедиційних, логістичних, перевізних підприємств.

Ключові слова: транспорті послуги, пасажирські перевезення, вантажні перевезення, структура ринку перевезень, логістичні послуги.
\end{abstract}

\section{ВСТУП}

Постійне, протягом п’яти років, зростання перевезень вантажів і пасажирів, викликає необхідність, на постійній основі, виконання оптимізації витрат на транспортування, що вимагає на основі статистичних даних досліджень економічної активності в транспортній галузі, встановлення об'єктивних закономірностей, динаміки та структурних особливостей ринку вантажних i пасажирських перевезень 3 обгрунтуванням тенденцій розвитку ринку транспортної та складської логістики. Врахування причинно-наслідкових зв’язків зміни об’ємів перевезень, за видами транспорту, дозволить визначити та виконати прогнозування, встановити, яким чином які основні замовники впливають на розвиток транспортної галузі. Розуміння реальних причин і тенденцій розвитку споживчого, оптового, та ринку логістики в Україні забезпечить можливість визначення, наскільки вони є збалансованими, для можливості оптимального управління транспортними компаніями.

\section{АНАЛІЗ ВІДОМИХ РЕЗУЛЬТАТІВ ДОСЛІДЖЕНЬ ТА ПОСТАНОВКА ПРОБЛЕМИ}

В теперішніх умовах вимагається проведення інноваційної модернізації без винятків в усіх галузях народного господарства, економічний вплив транспортної галузі. В Україні приріст обсягу перевезень вантажів за 2019 рік до 2018р. становив $+29,7 \%$, або $+55,5$ млн тонн. У 2019 році, за офіційними даними, було перевезено понад 1800 млн пасажирів, при цьому, відомо, до 80\% ринку пасажирських автомобільних перевезень перебуває в тіні [1, 2, 3]. Ліцензовані автоперевізники, які приймають участь в конкурсах з одержання ліцензій на маршрути, не перевищують $30 \%$ від загальної кількості автоперевізників [2, 3]. Функціонування і розвиток в Україні товарного і транспортного ринків як наслідок діяльності підприємств: транспортно - експедиційних, комерційнопосередницьких, перевізників, ін. комплексно детермінують тренди ринку транспортних послуг як об’єкту дослідження динаміки та структури вантажопотоків [1-5].

На сьогодні актуальним є проведення досліджень 3 аналізом основних тенденцій розвитку ринку вантажних та пасажирських транспортних послуг з метою одержання об'єктивних результатів, шляхом визначення факторів які, в досліджуваному періоді, впливають на розвиток підприємств транспортної галузі [6-10]. Аналітичні дослідження одержаних емпіричних даних 3 наступною 
формалізацією та обробкою є основою адекватного визначення показників обсягів перевезень, в тому числі інтермодальних та мультимодальних, видів вантажів, тенденцій попиту на перевезення за видами перевезень та транспорту, напрямками розміщення та об'ємів виробництв за видами продукції, перспективами підвищення прибутковості вантажних і пасажирських перевезень.

\section{ЦІЛЬ ТА ЗАДАЧІ ДОСЛІДЖЕННЯ}

За даними Державного комітету статистики України, Міністерства розвитку економіки, торгівлі та сільського господарства України [1-5] в грудні, в порівнянні з листопадом 2019 року, оборот роздрібної торгівлі зріс на 18,7\%, а в порівнянні з груднем 2018 року - на 12,5\%. Найбільше зростання обороту роздрібної торгівлі підприємств (як юридичних осіб так і фізичних осібпідприємців) в 2019 року, порівняно з 2018 роком, зафіксовано в Київській (на 20\%), Вінницькій (на $18,6 \%)$, Тернопільській (на 17,5\%), Луганській (на 16\%), Черкаській (на 14,8\%) областях і в Києві (на $15,1 \%)$. Значний внутрішній попит згенеровано відповідними показниками зростання в сферах будівництва, торгівлі та низки сегментів сфери послуг, основними замовниками транспортних послуг $\epsilon$ підприємства [1-5] дорожньої та будівельної галузей, які, разом з виробниками продукції рослинництва в аграрному секторі забезпечили збільшення обсягів перевезення вантажів автомобільним і залізничним транспортом. Індекс фізичного обсягу обороту роздрібної торгівлі у порівнянних цінах, 2018p. до 2019p., знизився [1-3]. Тенденції розвитку торгівлі: суттєве зменшення попиту при збільшенні оборотів, причинами збільшення яких є ріст цін при зменшенні обсягу реалізованих товарів, економічний спад, не прогнозованість політики та макроекономіки унеможливили залучення капіталу на IPO чи SPO, також пошук стратегічного інвестора; за рахунок негативних змін при роботі з товарними кредитами і запозиченими коштами радикально змінюється комплекс функцій дистрибуції [11 - 15]. На цій основі раціональним є прогнозування показників перевезень вантажів в середньо i довгостроковій перспективі. Необхідно враховувати, що прогнозування на основі статистичних даних є перенесенням подій минулих періодів на майбутні, застосування методів кореляційного та регресивного аналізу, екстраполяції часових рядів та евристичного прогнозування доцільно виконувати на основі і з урахуванням експертних фахових оцінок [3, 4, 10-15].

\section{РЕЗУЛЬТАТИ ДОСЛІДЖЕННЯ}

За оцінкою Міністерства розвитку економіки, торгівлі та сільського господарства України, протягом 2019 року динаміка змін (рис.1) у транспортній галузі була позитивною завдяки стабільному зростанню як вантажо-, так і пасажирообороту.

грудень 2019р. (листопад 2019p.)

Випуск ВЕД «Транспорт» ${ }^{1}, \%$
Вантажооборот,\%
Перевезення вантажів, \%
Пасажирооборот, \%
Перевезення пасажирів, \%

Динаміка вантажообороту/перевезення вантажів, у 2018-2019pp., \% (p/p)

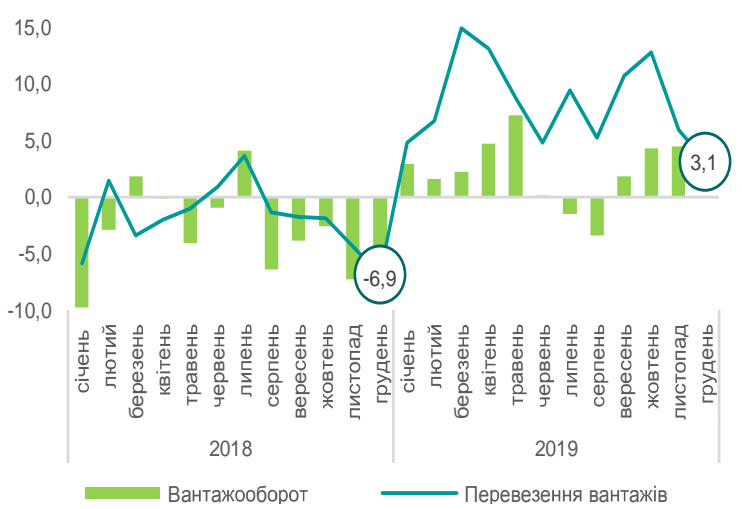

Рисунок 1. Динаміка вантажо - та пасажиро - обороту у 2018-2019pp. [3] 2019p. (2018p.)

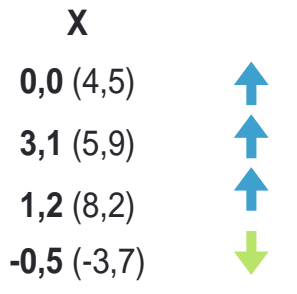

Динаміка пасажирообороту/перевезення пасажирів, у 2018-2019pp., \% (p/p)

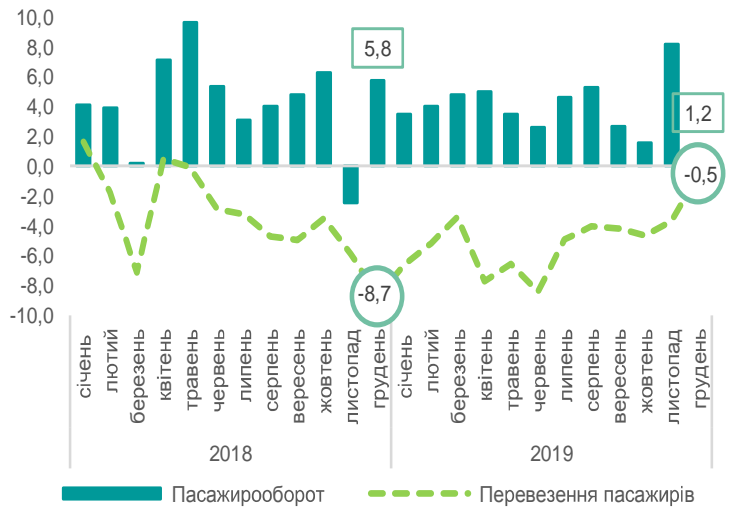


Діяльність вантажного транспорту (залізничний і автомобільний) підтримувалася завдяки попиту з боку агровиробників (новий рекордний врожай зернових культур 2019/20pp.) та будівельних підприємств (ремонт і будівництво інфраструктурних об'єктів) [1, 3]. Зростання на пасажирському транспорті забезпечувалося, в основному, завдяки активному розвитку авіаційного транспорту (лібералізація ринку авіаперевезень та активного функціонування авіа - лоукосткомпаній), рис. 2. Водночас падіння у практично всіх сегментах промисловості, як одного з найбільших користувачів транспортних послуг, а також збереження логістичних проблем у залізничному транспорті: періодичні затримки рухомого складу АТ «Укрзалізниця» у морських портах, також суттєвий рівень зносу рухомого складу стримували розвиток окремих сегментів транспортної галузі $[1,3]$.

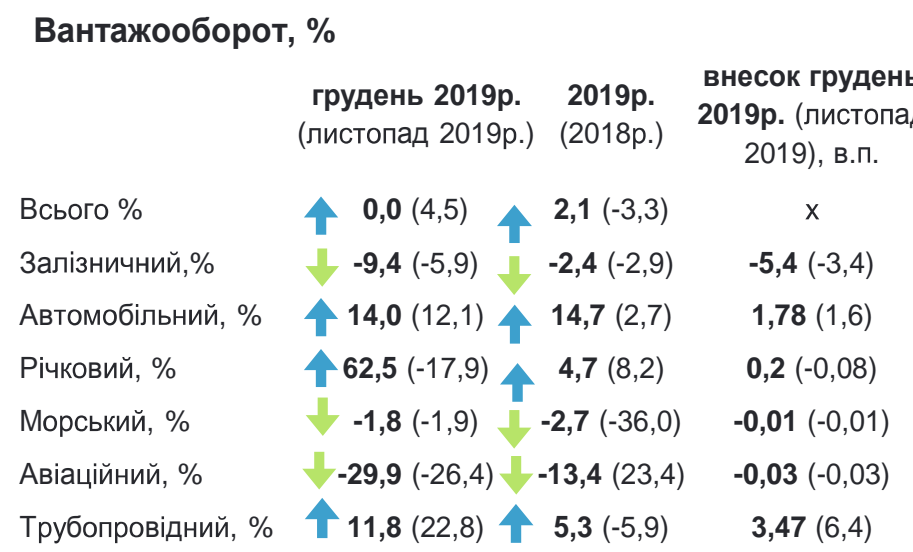

грудень 2019p. 2019p.

Всього \%

Залізничний,\%

Автомобільний, \%

Річковий, \%

Авіаційний, \%

Трубопровідний, \%

\section{Вантажооборот, \%}

$11,8(22,8)$ 个 $5,3(-5,9)$

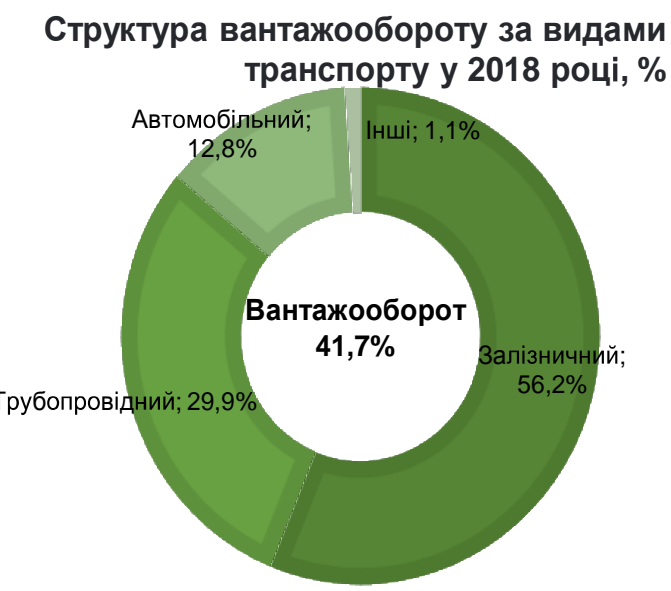

Структура пасажирообороту за видами транспорту у 2018 році, \%

Внесок грудень 2019p. (листопад 2019), в.п. $\begin{array}{cc}\text { грудень 2019p. } & \text { 2019p. } \\ \text { (листопад 2019p.) } & \text { (2018p.) }\end{array}$

Всього \%
Залізничний,\%
Автомобільний, \%
Водний, \%
Авіаційний, \%
Міський, \%

$1,2(8,2)$

$3,3(5,1)$

$-6,7(19,6)$

$0,0(2,2)$

$-2,1(-3,8)$

$0,0(-2,7)$

$-78,8(0)$

$16,0(23,5)$

$-6,5(-9,1)$

$4,9(-3)$

$16,1(27,2)$

$-4,4(-1,1)$

Джерело. Держстат, розрахунки Мінекономіки

Рисунок 2. Структура вантажообороту за видами транспорту [3]

За оцінками Meibach Logistik, Armstrong \& Associates, Inc. [16, 17], під впливами глобальних економічних негативних змін темпи росту ринків Китаю, Індії, Бразилії не зазнали змін, динаміка обсягу логістичного аутсорсингу в країнах Європи сповільнюється. Зрозуміло, у перспективі економічна кон'юнктура має негативний вплив на ринок логістики. У структурі світового ринку логістичних послуг частка транспортно-експедиторських послуг зменшилася, частка комплексних логістичних послуг (включаючи послуги зберігання і дистрибуції товарів) зросла, як і частка управлінської логістики $[16,17,19]$. Основою позитивного тренду динаміки торгівлі, відповідно інвестиційної привабливості ринків $\epsilon$ розвиток логістичної інфраструктури. Міжнародною фінансовою групою «Agility» запропоновано i успішно застосовується індекс розвитку ринку логістики Agility Emerging Markets Logistics Index, який відображає ступінь привабливості ринку логістики для інвестицій [19, 20].

За даним дослідженням, для ринків логістики які розвиваються, в оцінці внутрішніх можливостей логістики, Україна у 2020 р. піднялася на одну позицію у рейтингу на 29 місце, в 
порівняні з 2019p. (рис. 3 а). Щодо оцінки зовнішніх можливостей у логістиці, Україна погіршила рейтинг на чотири позиції (рис. 3 б). У рейтингу можливостей для бізнесу наша держава піднялася на десять позицій [16 - 20].

\begin{tabular}{|l|l|l|c|}
\hline Rank & $\begin{array}{l}\text { Domestic } \\
\text { Logistics Index }\end{array}$ & Score & $\begin{array}{c}\text { YoY } \\
\text { Change }\end{array}$ \\
\hline 1 & China & 8.87 & - \\
\hline 2 & India & 8.05 & - \\
\hline 3 & Indonesia & 6.33 & - \\
\hline 4 & UAE & 5.57 & 1 \\
\hline 5 & Brazil & 5.49 & -1 \\
\hline 6 & Saudi Arabia & 5.44 & 3 \\
\hline 7 & Qatar & 5.39 & -1 \\
\hline 8 & Mexico & 5.36 & -1 \\
\hline 9 & Malaysia & 5.30 & 1 \\
\hline 10 & Turkey & 5.17 & -2 \\
\hline 11 & Russia & 5.17 & 1 \\
\hline 12 & Kuwait & 5.13 & 1 \\
\hline 13 & Egypt & 5.09 & 6 \\
\hline 14 & Thailand & 5.09 & 6 \\
\hline 15 & Pakistan & 5.09 & -4 \\
\hline 16 & Nigeria & 5.05 & 9 \\
\hline 17 & Bahrain & 5.01 & -3 \\
\hline 18 & Oman & 4.98 & -1 \\
\hline 19 & Philippines & 4.98 & -4 \\
\hline 20 & Bangladesh & 4.95 & -2 \\
\hline 21 & Vietnam & 4.94 & 1 \\
\hline 22 & Argentina & 4.93 & -6 \\
\hline 23 & Algeria & 4.92 & 1 \\
\hline 24 & Jordan & 4.91 & -1 \\
\hline 25 & Lebanon & 4.89 & -4 \\
\hline 26 & Chile & 4.86 & 1 \\
\hline 27 & Iran & 4.85 & -1 \\
\hline 28 & Uruguay & 4.82 & - \\
\hline 29 & Ukraine & 4.79 & 1 \\
\hline 30 & Kazakhstan & 4.73 & -1 \\
\hline 31 & Peru & 4.72 & 1 \\
\hline 32 & Colombia & 4.71 & -1 \\
\hline 33 & South Africa & 4.64 & - \\
\hline 34 & Tunisia & 4.62 & 4 \\
\hline 35 & Morocco & 4.62 & -1 \\
\hline 37 & Tanzania & 4.61 & 1 \\
\hline & Kenya & 4.59 & 5 \\
\hline
\end{tabular}

a)

\begin{tabular}{|c|c|c|c|}
\hline Rank & $\begin{array}{l}\text { Business } \\
\text { Fundamentals } \\
\text { Index }\end{array}$ & Score & $\begin{array}{l}\text { YoY } \\
\text { Change }\end{array}$ \\
\hline 1 & UAE & 9.33 & - \\
\hline 2 & Malaysia & 8.23 & - \\
\hline 3 & Saudi Arabia & 8.17 & 2 \\
\hline 4 & Qatar & 8.11 & -1 \\
\hline 5 & Bahrain & 7.51 & 3 \\
\hline 6 & Chile & 7.40 & - \\
\hline 7 & Oman & 7.29 & -3 \\
\hline 8 & China & 7.17 & -1 \\
\hline 9 & Jordan & 6.69 & 4 \\
\hline 10 & Morocco & 6.69 & -1 \\
\hline 11 & Kazakhstan & 6.39 & 5 \\
\hline 12 & Kuwait & 6.06 & -1 \\
\hline 13 & Uruguay & 5.98 & -1 \\
\hline 14 & Thailand & 5.97 & 1 \\
\hline 15 & Indonesia & 5.95 & -1 \\
\hline 16 & Turkey & 5.77 & 2 \\
\hline 17 & Egypt & 5.74 & 10 \\
\hline 18 & India & 5.70 & -8 \\
\hline 19 & Russia & 5.45 & -2 \\
\hline 20 & Vietnam & 5.37 & - \\
\hline 21 & South Africa & 5.16 & 3 \\
\hline 22 & Tanzania & 5.13 & 3 \\
\hline 23 & Kenya & 4.94 & -2 \\
\hline 24 & Mexico & 4.91 & -1 \\
\hline 25 & Tunisia & 4.87 & -3 \\
\hline 26 & Algeria & 4.81 & 2 \\
\hline 27 & Ukraine & 4.64 & 10 \\
\hline 28 & Colombia & 4.49 & 3 \\
\hline 29 & Sri Lanka & 4.49 & 3 \\
\hline 30 & Philippines & 4.47 & 4 \\
\hline 31 & Peru & 4.47 & -2 \\
\hline 32 & Ghana & 4.47 & -13 \\
\hline 33 & Ecuador & 4.46 & -3 \\
\hline 34 & Uganda & 4.40 & 9 \\
\hline 35 & Pakistan & 4.34 & -2 \\
\hline 36 & Cambodia & 4.19 & 4 \\
\hline 37 & Lebanon & 4.14 & -2 \\
\hline
\end{tabular}

б)

Рисунок 3. Оцінка внутрішніх (а) та зовнішніх (б) можливостей ринків логістики [19]

Рівень інвестиційної привабливості оцінюється за сукупністю показників: розвиток транспортних комунікацій, величини і динаміки розвитку, ринкової сумісності [19, 20, 21-23]. Рейтинг країн згідно Agility Emerging Markets Logistics Index 2019, в тому числі з деталізацією за субіндексами наведено в $[19,20]$. Україна $[14,19,20,21]$ знизила показники, змістившись більше 10 позицій вниз. За даними Agility Emerging Markets Logistics Index [19, 20] оцінка України погіршилася, субіндекс розміру і привабливості ринку також знизився. Потоки FDI в Україну зменшились, це $\epsilon$ найнижчим рівнем за 15 років $[16,17,19,20]$.

\section{ОБГОВОРЕННЯ РЕЗУЛЬТАТІВ ДОСЛІДЖЕНЬ}

Встановлено, у 2018-2019pр. на вантажні перевезення найбільш впливали: зростання попиту на природний газ у країнах СС на фоні низької вартості; високий внутрішній попит з боку будівельних підприємств, агровиробників та підприємств роздрібної торгівлі; запровадження у 2019р. графікових відправлень АТ «Укрзалізниця» зернових вантажів за узгодженим графіком руху - закольцовані регулярні відправлення «елеватор-порт» [1 - 3]. Зниження (порівняно з 2018 роком) цін на паливо та мастила (курс валют); відкриття нових маршрутних станцій із прискореним завантаженням. На пасажирський транспорт впливали такі фактори: функціонування на ринку перевезень пасажирів авіа лоукост- компаній, навіть враховуючи банкрутства (наприклад «FlyErnest»), а також відчутне здорожчання (порівнюючи 3 базовим у даному дослідженні 2018 роком) вартості транспортних послуг залізничного пасажирського транспорту [1-3]. 
Встановлено, в 2015-2019 pр. спостерігалось коливання попиту на вантажні автомобільні перевезення, обсяги виконаної роботи змінювалися [1-3]. В [1, 3, 4] доведено, що структура парку вантажних автомобілів українських підприємств, зокрема працюючих на внутрішніх перевезеннях, суттєво не змінилася та не відповідає попиту - більшість вантажівок $є$ морально застарілими. Встановлено що вантажопідйомність до 90\% вантажівок становить 1,5 - 10 т., структура парку автомобільного транспорту в Україні така, що близько 70\% вантажних автомобілів експлуатуються понад 10 р., що призводить до збільшення витрат на перевезення [1-3]. У 2015 р. - 2019pр., до 50 \% сумарного пробігу вантажного автотранспорту склав пробіг з вантажем [1-3]. За структурою експортно - імпортних та транзитних операцій, частка автотранспорту $12 \%$, залізничного $56,2 \%$, трубопровідного 29,9\%. У порівняні з 2010-2015p. частка автоперевезень зросла на 5\%, залізничних на $6 \%$.

Транзитне перевезення вантажів автомобільним транспортом зросло, щорічно усереднене збільшення обсягу транзитних перевезень автомобільним транспортом складало до 900 тис. т. $[1,2]$. В загальному обсязі транзитних вантажопотоків частка автомобільного транспорту зросла, що засвідчує підвищення рівня використання транзитного потенціалу країни 3 позицій автомобільних перевезень. Експорт транспортних послуг становить 21,3\% від загальносвітового експорту комерційних послуг, в Україні частка імпорту досягає $0,4 \%$, експорту - $1,0 \%$ на загальносвітовому ринку транспортних послуг. В країнах СС здійснюється 32,1\% імпорту і 43,2\% загальносвітового експорту транспортних послуг $[6,9]$. Зокрема, згідно зі статистикою $\mathrm{CC}$, на міжнародні перевезення товарів морськими шляхами припадає до $55 \%$, автодорожніми до $22 \%$, залізничними до $3 \%$, повітрям до $24 \%$ [7, 9]. За мультимодальною схемою перевезень здійснюється понад 50\% світового зовнішньоторговельного товарообміну, 3 яких $75 \%$ ринку контролюється транспортно експедиторськими кампаніями, або логістичними операторами [8, 9, 10-15].

\section{ВИСНОВКИ}

На основі досліджень економічної активності в транспортній галузі країни визначено основні залежності, динаміку та структурні особливості ринку пасажирських та вантажних перевезень, а також тенденції розвитку ринку транспортної логістики, з урахуванням пасажирських та вантажних потоків за видами транспорту. Встановлено, що основними замовниками $є$ підприємства дорожньої та будівельної галузей, які, разом з агросектором, зокрема, виробниками продукції рослинництва, забезпечили суттєве збільшення обсягів перевезень вантажів автомобільним і залізничним транспортом. Частка автомобільного транспорту в транспортній системі країни зростає при позитивному тренді попиту на перевезення вантажів, матиме місце тривалий динамічний розвиток галузі в цілому. Споживчий, оптовий, та ринок логістики в Україні мають близькі тренди розвитку, визначено, що вони є збалансованими, ринок логістичних послуг та вантажних перевезень має стійку тенденцію розвитку при об'єктивному зниженні темпів росту.

\section{ПЕРЕЛІК ДЖЕРЕЛ ПОСИЛАННЯ}

1. Державний комітет статистики України [Електрон. ресурс]. - Режим доступу: http://www.ukrstat.gov.ua.

2. Міністерство інфрастуктури України [Електрон. ресурс]. - Режим доступу: http://www.mintrans.gov.ua.

3. Міністерство економіки України [Електрон. ресурс]. - Режим доступу: https://www.me.gov.ua/Documents/List?lang=uk-UA\&id=f9c84884-09b4-42ff-9b8a-

$8924586 \mathrm{e} 9 \mathrm{~d} 72 \&$ tag=docs_project

4. Н. М. Іщенко. Маркетинг транспортних послуг. [Електрон. ресурс]. - Режим доступу: http://lib.chdu.edu.ua/pdf/posibnuku/333/4.pdf.

5. Гурч Л.М., Ченчик А.М. Маркетингове дослідження ринку транспортних послуг України //Логістика. - №633. - 2008.

6. International Trade Statistics 2011, Statistic database WTO // Source: http://www.wto.org

7. EU: Transport in Figures 2011 // Source: http://ec.europa.eu/transport/publications/statistics/ doc/2012/pocketbook2012.pdf

8. Підлісний П.І. Стан та тенденції розвитку змішаних вантажних перевезень / Підлісний П.І., Брайковська А.М. // Зб. наукових праць, ДЕТУТ, «Економіка та управління», вип. 19, 2012 р. - С. 162166. 
9. Брайковська А. М. Дослідження особливостей формування ринку транспортних послуг як середовища функціонування підприємств транспорту / А. Брайковська // Економіст. - 2012. - № 9. C.50-54.

10. Попович П. В. Аналітичні технології в забезпеченні економічної ефективності логістичних систем / Попович П. В. // Вісник ХНТУСГ. - Харків, 2016. - Вип. № 169. - С. 223 - 225.

11. Шевчук О.С. Вплив показників ефективності на безпеку руху вулично-дорожними мережами/ Шевчук О. С. // Вісник ХНТУСГ. - Харків, 2016. - Вип. № 169. - С. 205 - 209.

12. Попович П. В. Дослідження тенденцій розвитку ринку вантажних автомобільних перевезень у сучасних умовах / П. В. Попович, О. С. Шевчук, А. Й. Матвї̈шин, В. М. Лотоцька // Вісник Житомирського державного технологічного університету. Серія : Технічні науки. - № 2. 2016. - C. 224-229.

13. Попович П.В. Підвищення ефективності технологій перевезень організаційними шляхами надання транспортних послуг / Попович П., Шевчук О., Мурований I. // Вісник ХНТУСГ. - Харків, 2017. - Вип. № 184. - С. 124 - 130.

14. Держкомстат України [Електрон. ресурс]. - Режим доступу: http://ukrstat.org/uk/operativ

15. Попович П.В. Економічні аспекти використання послуг 3PL операторів вітчизняними підприємствами. Науковий журнал. - Луцьк: Луцький НТУ, 2016. № 2. С. 125-129.

16. Meibach Logistik [Електрон. ресурc]. - Режим доступу: http://www.miebach.com

17. A\&A’s [Електрон. pесурс]. - Режим доступу: http://www.3plogistics.com/

18. Тюріна Н. М. Логістика [Текст]: Навч. посіб. / Н. М.Тюріна, І. В. Гой,. І. В. Бабій. - К.: «Центр учбової літератури», 2015. - 392 с.

19. http://www.agility.com

20. http://www.agility.com/EN/About-Us/Pages/AEMLI-2019-Size-and-Growth-Attractiveness.aspx

21. Пасічник А. М. роблеми та перспективи розвитку логістичного аутсорсингу в транспортній системі України / А. М. Пасічник, І. Г. Лебідь, В. В. Кутирєв, К. М. Бугерко // Управління проектами, системний аналіз і логістика. - 2014. - Вип. 14(1). - С. 146-159.

22. УВК [Електрон. ресурс]. - Режим доступу: http://www.uvk.ua/ua/reviews

23. Шевчук О. С. Порушення при облаштуванні паркувальних місць транспортних засобів на вулично-дорожній мережі міста// Сучасні технології в машинобудуванні та транспорті. - №1. - 2016. - C. 167-171.

\section{REFERENCES}

1.Derzhavnyi komitet statystyky Ukrainy [Elektron. resurs]. - Rezhym dostupu: http://www.ukrstat.gov.ua.

2.Ministerstvo infrastuktury Ukrainy [Elektron. resurs]. - Rezhym dostupu: http://www.mintrans.gov.ua.

3.Ministerstvo ekonomiky Ukrainy [Elektron. resurs]. - Rezhym dostupu: https://www.me.gov.ua/Documents/List?lang=uk-UA\&id=f9c84884-09b4-42ff-9b8a8924586e9d72\&tag=docs_project

4.Ishchenko N. M.(2014). Marketynh transportnykh posluh. [Elektron. resurs]. - Rezhym dostupu : http://lib.chdu.edu.ua/pdf/posibnuku/333/4.pdf.

5.Hurch, L.M., Chenchyk, A.M. (2008). Marketynhove doslidzhennia rynku transportnykh posluh Ukrainy. Lohistyka, 23, 633.

6. International Trade Statistics (2011). Statistic database WTO . Source: http://www.wto.org

7. EU: Transport in Figures (2011). Source: http://ec.europa.eu/transport/publications/statistics/ doc/2012/pocketbook2012.pdf

8.Pidlisnyi, P.I. (2012). Stan ta tendentsii rozvytku zmishanykh vantazhnykh perevezen. Ekonomika ta upravlinnia, 19, 162-166.

9.Braikovska, A. M. (2012). Doslidzhennia osoblyvostei formuvannia rynku transportnykh posluh yak seredovyshcha funktsionuvannia pidpryiemstv transport. Ekonomist, 9, 50-54.

10.Popovych, P. V. (2016). Analitychni tekhnolohii v zabezpechenni ekonomichnoi efektyvnosti lohistychnykh system. Visnyk KhNTUSH, 169, 223 - 225.

11.Shevchuk, O.S. (2016). Vplyv pokaznykiv efektyvnosti na bezpeku rukhu vulychno-dorozhnymy merezhamy. Visnyk KhNTUSH, 169, 205 - 209. 
12.Popovych, P. V. (2016). Doslidzhennia tendentsii rozvytku rynku vantazhnykh avtomobilnykh perevezen u suchasnykh umovakh. Visnyk Zhytomyrskoho derzhavnoho tekhnolohichnoho universytetu, 2, 224-229.

13.Popovych, P.V. Shevchuk, O.S., Murovanyi I. S. (2017). Pidvyshchennia efektyvnosti tekhnolohii perevezen orhanizatsiinymy shliakhamy nadannia transportnykh posluh. Visnyk KhNTUSH, 184, 124 - 130.

14.Derzhkomstat Ukrainy [Elektron. resurs]. - Rezhym dostupu: http://ukrstat.org/uk/operativ

15.Popovych, P.V. (2016). Ekonomichni aspekty vykorystannia posluh 3PL operatoriv vitchyznianymy pidpryiemstvamy. Suchasni texnologiyi v mashy`nobuduvanni ta transporti, 2, 125-129.

16.Meibach Logistik [Elektron. resurs]. - Rezhym dostupu: http://www.miebach.com

17.A\&As [Elektron. resurs]. - Rezhym dostupu: http://www.3plogistics.com/

18.Tiurina N. M. Lohistyka (2015). Navch. Posib, 392.

19.http://www.agility.com

20.http://www.agility.com/EN/About-Us/Pages/AEMLI-2019-Size-and-Growth-Attractiveness.aspx

21.Pasichnyk, A. M., Lebid, I. H. Kutyriev, V. V. Buherko, K. M. (2014). Problemy ta perspektyvy rozvytku lohistychnoho autsorsynhu $\mathrm{v}$ transportnii systemi Ukrainy. Upravlinnia proektamy, systemnyi analiz i lohistyka, 14(1), 146-159.

22.UVK [Elektron. resurs]. - Rezhym dostupu: http://www.uvk.ua/ua/reviews.

23.Shevchuk, O.S. (2016). Porushennya pry` oblashtuvanni parkuval`ny`x miscz` transportny`x zasobiv na vuly`chno-dorozhnij merezhi mista. Suchasni texnologiyi v mashy`nobuduvanni ta transporti, 1 , 167-171.

M. Maiak, P. Prohnii, A. Matviyishyn, P. Popovych, O. Shevchuk, V. Ostroverkhov, A.Kotsur, O. Romanyshyn. Features of the development of the market of cargo and passenger transportation

The analysis of the basic tendencies of development of the market of freight and passenger transportations is carried out, the basic factors influencing development of the transport enterprises are investigated. A review of economic activity in the transport sector of the country. The main dependences, dynamics and structural features of the market of passenger and freight transportation, as well as trends in the market of transport logistics, including passenger and freight flows by mode of transport, are studied. It is established that the main customers are enterprises of road and construction industries, as well as agricultural enterprises, mainly producers of crop products in the agricultural sector, which in the complex provided an increase in freight transportation by road and rail. Over the last five years, the share of road transport in the country's transport system is projected to continue to grow based on the positive trend of increasing demand for freight for these industries, so there will be a long dynamic development of Ukraine's transport industry as a whole. The market of logistics services and the consumer market have related directions of development, it is established that they are balanced, in general, the market of road and rail transport has a stable upward trend with a possible slowdown. The results of the study can be used as a basis for modeling the main trends of the freight market, as well as passengers, based on the results of the study of factors influencing the development of transport enterprises of the country, which will qualitatively influence the improvement or updating of planning tools, transportation companies.

Keywords: transport services, passenger transportation, cargo transportation, transportation market structure, logistics services.

МАЯК Микола Михайлович, доктор технічних наук, професор, професор кафедри автомобілів і транспортних технологій, Луцький національний технічний університет, Луцьк, Україна, e-mail: maiak48@mail.ru

ПРОГНІЙ Павло Богданович, кандидат технічних наук, ст.викл. кафедри спеціалізованих комп’ютерних систем, Західноукраїнський національний університет, Тернопіль, Україна, e-mail: PPopovuch@gmail.com

МАТВІЇШИН Анатолій Йосипович, кандидат технічних наук, доцент, доцент кафедри транспортних технологій, Тернопільський національний технічний університет імені Івана Пулюя, еmail: AMatviishyn@ukr.net

ПОПОВИЧ Павло Васильович, доктор технічних наук, професор, професор кафедри спеціалізованих комп'ютерних систем, Західноукраїнський національний університет, Тернопіль, Україна, e-mail: PPopovich@ukr.net. https://orcid.org/0000-0001-5516-852X 
ШЕВЧУК Оксана Степанівна, кандидат технічних наук, доцент, доцент кафедри спеціалізованих комп'ютерних систем, Західноукраїнський національний університет, Тернопіль, Україна, e-mail: oksana_shevchuk84@ukr.net. https://orcid.org/0000-0001-8283-4620

ОСТРОВЕРХОВ Віктор Михайлович, кандидат економічних наук, доцент, доцент кафедри менеджменту, публічного управління та персоналу, Західноукраїнський національний університет, Тернопіль, Україна, e-mail: v.ostroverkhov@wunu.edu.ua. http://orcid.org/0000-0002-3818-0604

КОЦУР Андрій Семенович, кандидат економічних наук, доцент, доцент кафедри менеджменту, публічного управління та персоналу, Західноукраїнський національний університет, Тернопіль, Україна, e-mail: a.kotsur@wunu.edu.ua. http://orcid.org/0000-0001-6986-4665

РОМАНИШИН Ольга Василівна, кандидат економічних наук, ст.викл. кафедри менеджменту, публічного управління та персоналу, Західноукраїнський національний університет, Тернопіль, Україна, e-mail: oksana_shevchuk84@ukr.net

Mykola MAIAK, Doctor of Sciences, Professor, Professor of the Department of Automobiles and Transport Technologies, Lutsk National Technical University, Lutsk, Ukraine, e-mail: maiak48@mail.ru

Pavlo PROHNII, Doctor of Philosophy, Senior Lecturer of Specialized Computer Systems department, West Ukrainian National University, Ternopil, Ukraine, e-mail: PPopovuch@gmail.com

Anatolyj MATVIYISHYN, Doctor of Philosophy, Associate Professor, Associate Professor of Automobiles department, Ternopil National Technical University Ivan Pul'uj, e-mail: AMatviishyn@ukr.net

Pavlo POPOVYCH, Doctor of Sciences, Professor, Professor of Specialized Computer Systems department, West Ukrainian National University, Ternopil, Ukraine, e-mail: PPopovich@ukr.net. https://orcid.org/0000-0001-5516-852X

Oksana SHEVCHUK, Doctor of Philosophy, Associate Professor, Associate Professor of Specialized Computer Systems department, West Ukrainian National University, Ternopil, Ukraine, e-mail: oksana_shevchuk84@ukr.net.https://orcid.org/0000-0001-8283-4620

Viktor OSTROVERKHOV, Doctor of Philosophy, Associate Professor, Associate Professor of Department of Management, Public Administration and Personnel, West Ukrainian National University, Ternopil, Ukraine, e-mail: v.ostroverkhov@wunu.edu.ua. http://orcid.org/0000-0002-3818-0604

Andriy KOTSUR, Doctor of Philosophy, Associate Professor, Associate Professor of Department of Management, Public Administration and Personnel, West Ukrainian National University, Ternopil, Ukraine, e-mail: a.kotsur@wunu.edu.ua. http://orcid.org/0000-0001-6986-4665

Olga ROMANYSHYN, Doctor of Philosophy, Senior Lecturer of Department of Management, Public Administration and Personnel, West Ukrainian National University, Ternopil, Ukraine, e-mail: oksana_shevchuk84@ukr.net

DOI 10.36910/automash.v2i15.393 